Historia Slavorum Occidentis

2017, $\mathrm{nr} 4(15)$

ISSN 2084-1213

DOI: $10.15804 /$ hso 170404

Ryszard Tomczyk (SzCzecin)

\title{
Zwyczaje pogrzebowe i usługi pogrzebowe polskiego Lwowa na przełomie XIX i XX w.
}

Słowa kluczowe: Galicja, Lwów, cmentarze, obyczaj pogrzebowy, usługi pogrzebowe

Keywords: Galicia, Lvov, cemeteries, burial rituals, funerary services

\begin{abstract}
The article's goal is to highlight burial rituals and funerary services in the Polish community in Lvov in the late $19^{\text {th }}$ and the early $20^{\text {th }}$ centuries as the issues are rarely discussed in academic research. Poles (who prevailed in the city) were typically Roman Catholics. The funerary ritual was modelled by the Catholic tradition. In the last decades of the $19^{\text {th }}$ century, funeral parlours emerged in Lvov to render services to the city's affluent and poor inhabitants alike.
\end{abstract}

Pogrzeby na dawnych Ziemiach Wschodnich Rzeczypospolitej miały mniej lub bardziej uroczystą oprawę. Wszystko zależało od pozycji społecznej i finansowej zmarłej osoby. Biedotę często grzebano bezimiennie w zbiorowych mogiłach, przy bardzo skromnym obrządku, w całunie, bez trumny. Jeżeli już zmarłego nędzarza złożono w trumnie to była to taka, którą wykorzystywano jedynie do przewiezienia zwłok na cmentarz. W podobny sposób odbywał się pogrzeb ludzi zmarlych w szpitalach miejskich lub przytułkach. Bogatą oprawę miały pogrzeby magnacko-szlacheckie oraz dobrze sytuowanych mieszczan. Także i wśród bogatszego chłopstwa zdarzały się bardziej uroczyste pogrzeby. Na nic się zdały zalecenia synodów biskupich w XVII i XVIII w. o skromność i umiarkowanie w celebrowaniu uroczystości pogrzebowych. Nadmierny przepych, wydawanie znacznych sum pieniędzy na obrzędy pogrzebowe budził niezadowolenie hierarchów Kościoła. Czasem się 
zdarzało, że nawet na wiejskich stypach masowo zjawiał się okoliczny „prosty lud”, który siał zgorszenie ze względu na pijaństwo, zaś wieśniacy na takie uroczystości wydawali duże środki, podcinając sytuację materialną swoich gospodarstw. Biskupi domagali się od właścicieli wsi ukrócenia tego procederu. Lepiej sytuowane rodziny mieszczańskie zabiegały o to, aby ich bliscy byli składani do pojedynczych grobów. Uroczystości pogrzebowe bogatych patrycjuszy miały podniosły charakter. Trumny były spowite czarnym materiałem na znak żałoby lub szarym na znak pokuty. Często też bogaci patrycjusze trumnę zdobili drogimi tkaninami w czerwonym kolorze. Tradycja lwowska nakazywała, aby ciało w trumnie było niesione na cmentarz przez wyznaczonych „do mar noszenia” członków cechu, do którego należał zmarły. Zresztą cechy uznawały za swój obowiązek odprowadzenie zmarłego, a także gdy zmarł członek jego rodziny, na miejsce wiecznego spoczynku. Przywiązanie parafian, szczególnie o wyższym statusie społecznym do pochówku w pojedynczym grobie na cmentarzach przykościelnych, na „bożej roli” było powszechne, uznawane za godne majestatu śmierci. Aby miejsce pochówku było godne pozycji, jaką zmarły miał za życia, rodziny wznosily kaplice o wykwintnej architekturze. We Lwowie w czasach I Rzeczypospolitej w kryptach kościelnych i klasztornych chowano duchownych, fundatorów i dobroczyńców kościelnych, zasłużonych dla miasta obywateli.

Pogrzeby, szczególnie bogatych mieszczan, szlachciców i magnatów na Ziemi Lwowskiej w przedrozbiorowej Polsce czasem odbywały się z udziałem orkiestry, przy wystrzałach z broni palnej. W pierwszej połowie XVIII w. synody biskupów na ziemiach polskich zakazywały na pogrzebach arystokratów wprowadzania koni do kościoła, organizowania pokazów na wzór turniejów rycerskich, gdzie łamano kopie i spadano z koni. Władze kościelne, między innymi synod lwowski w 1765 r., zalecał proboszczom chowanie biednych bez pobierania opłaty, niemniej zgodnie z ceremoniałem, niezbędną procesją, krzyżem i śpiewem. Tradycyjne kondukty pogrzebowe, szczególnie osób znanych, ściągały rzesze uczestników i trwały bardzo długo. Na przykład kondukt pogrzebowy wielkiego hetmana koronnego Adama Sieniawskiego, który zmarł we Lwowie 10 II 1724 r., wyruszył z Niskiego Zamku o godzinie piątej po południu, dopiero o trzeciej w nocy dotarł do kościoła św. Piotra i Pawła na przedmieściu Łyczakowskim. Równie wystawny pogrzeb zmarłej we Lwowie wojewodziny ruskiej Joanny Jabłonowskiej odbył się 21 III 1744 r. Wystawne pogrzeby odbywały się w innych miastach wschodniej Polski. Na przykład kilka dni trwał pogrzeb hetmana Stanisława Potockiego w 1751 r. w Stanisławowie, który spoczął w podziemiach miejscowej kolegiaty. Przykładów wystawnych pogrzebów w czasach dawnej Rzeczypospolitej można mnożyć. Bogata oprawa pogrzebów bu- 
dziła zdziwienie przybyszów z innych państw oraz refleksje części Polaków. Wybitny profesor matematyki kolegium jezuickiego we Lwowie o. Faustyn Grodzicki w podręczniku o pirotechnice wydanym we Lwowie w 1747 r., nie pochwalał urządzania fajerwerków oraz iluminacji z okazji pogrzebów, gdyż te przypominały uroczystości weselne. Natomiast na podobieństwo wesel, z drużbami, odbywały się w mieście pogrzeby dzieci. Należy podkreślić, że wiele wystawnych pogrzebów w XVIII w. we Lwowie odbywało się na cmentarzach, na których był wręcz wyczuwalny nawet z dalszej odległości fetor rozkładających się ciał. Dlatego mieszkańcy żyli w obawie, że niebezpieczne miazmaty rozkładających się dużych ilości zwłok na bardzo ograniczonych pod względem terenu cmentarzach przykościelnych przenikały do gleb i do wody w studniach ${ }^{1}$. Mieszkańcy Ziemi Lwowskiej ze względu na masowe epidemie, głód, częste wojny i zwykłe przestępstwa kryminalne niemal codziennie obcowali ze śmiercią. Rozpowszechnionym zwyczajem było sprawianie sobie trumny za życia, które przechowywano czasem długie lata w domostwach. Zakupioną za życia trumnę często wypełniano ziarnem zbóż. Zgodnie ze zwyczajem trumna pełna ziarna miała przysparzać dobrobytu, jeśli jednak ziarno zaczęło się z trumny wysypywać, uznawano to za niewątpliwy znak zbliżającej się śmierci². Na katolickich cmentarzach przykościelnych znajdujących się w obrębie murów obronnych Lwowa tradycyjnie od średniowiecza w uroczysty sposób obchodzono Wszystkich Świętych i Dzień Zaduszny. Żywi okazywali szacunek na cmentarzach zmarłym zgodnie z prastarą tradycją słowiańską, pielęgnowaną przy starych drewnianych cerkwiach i kościołach. W dawnych czasach ludzie odwiedzali zwyczajowo cmentarze, odprawiali obrzędy, na mogiłach stawiali „misy pełne twarogów i miodu”. W późniejszych czasach na cmentarzach rzymskokatolickich utrwalił się zwyczaj składania wieńców, kwiatów, zapalania świec i lampek, które dziś nazywamy zniczami. Na Cmentarzu Łyczakowskim we Wszystkich Świętych na przełomie XIX i XX w. młodzież co roku śpiewała na mogiłach powstańców z 1863 r. pieśni patriotyczne. Żyjący w tym czasie Mieczysław Opałek podkreślał, że zwyczaj śpiewów patriotycznych na grobach, kultywowany z roku na rok „posiadał moc i urok tradycji. Liczna grupa, złożona z młodzieży akademickiej i uczniów szkół średnich, nawiedzała corocznie cmentarz w święto zmarłych. Jako wyraz kultu dozwolone były zebrania i śpiewy na grobach,

1 Ł. Charewiczowa, Klęski zaraz w dawnym Lwowie, Lwów 1930, s. 15.

2 Na temat zwyczajów i przesądów związanych ze śmiercią i obrządkami pogrzebowymi istnieje bogata literatura. Zob. między innymi: A. Fischer, Zwyczaje pogrzebowe ludu polskiego, Lwów 1921.

3 M. Opałek, Paparówka. Zapomniany cmentarz lwowski, Kurier Lwowski, 30 X 1916, nr 544. 
nielegalny natomiast bywał epilog tych manifestacji, przybierający formy demonstracyjnego powrotu z cmentarza do miasta. Uszykowani w czwórki, przeciągali manifestanci ulicą Piekarską ze śpiewem na ustach”4. Również w okresie pierwszej wojny światowej młodzież manifestowała postawę patriotyczną na Cmentarzu Łyczakowskim pod krzyżem powstańców z 1863 r., przy pomniku Ordona i innych grobach patriotów. Niemniej w czasie pierwszej wojny światowej pojawiły się zarządzenia władz cywilnych i wojskowych zakazujące palenia na cmentarzach świec i lampek w okresie Wszystkich Świętych i Dni Zadusznych. W ten sposób władze chciały ograniczyć zużycie tłuszczu, gdyż państwo znalazło się w trudnej sytuacji aprowizacyjnej. We Lwowie brakowało w tym czasie świec, nafty czy mydła. Należy dodać, że w 1876 r. zakazano we Lwowie w trakcie przemarszu konduktu pogrzebowego na dwa działające wówczas cmentarze: Łyczakowski ${ }^{5}$ i Stryjski ${ }^{6}$ (Cmentarz

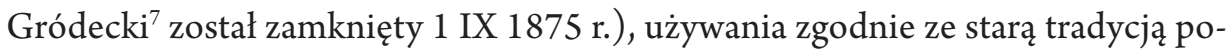
chodni smolnych, które wydzielały na ulicach nieprzyjemną woń. Można było w to miejsce używać świec woskowych.

Inną sprawą było utrzymanie w tym czasie porządku na istniejących cmentarzach przez służbę miejską podległą magistratowi lwowskiemu. Zgodnie z tradycją chrześcijańską i obowiązującym prawem należał się szacunek dla szczątków ludzkich, które spoczywały w „poświęconej roli”. Niestety, na przykład w górnej części Cmentarza Łyczakowskiego zgodnie $\mathrm{z}$ alarmującymi informacjami zawartymi w prasie walało się latem 1881 r. mnóstwo ludzkich kości i kawałków, starych butwiejących kawałków trumien. Redakcja „Dziennika Polskiego” zwracała się do magistratu, aby polecił zatrudnionemu na Cmentarzu Łyczakowskim grabarzowi Tchórzewskiemu „pozakopywać te fragmenta”. Gazeta z 10 VII 1881 r. zwracała uwagę, że „parobcy używają do spuszczania trumien do grobu starych sznurów sztukowanych. Wczoraj właśnie sznur taki przerwał się spuszczaniu zwłok do grobu”. Brak nadzoru ze

4 M. Opałek, O Lwowie i mojej mtodości, Wrocław 1987, s. 174-175.

5 Na temat Cmentarza Łyczakowskiego istnieje bardzo bogata literatura naukowa i popularnonaukowa. Zob. między innymi: A. Medyński, Ilustrowany przewodnik po cmentarzu Łyczakowskim, Lwów 1937; S.S. Nicieja, Cmentarz Łyczakowski we Lwowie, Wrocław 1988 (wyd. I); tenże, Ogród snu i pamięci. Dzieje Cmentarza Eyczakowskiego we Lwowie oraz ludzi tam spoczywających w latach 1786-2010, Opole 2010; K. Łoza, Cmentarz Eyczakowski we Lwowie. Przewodnik, Wrocław 2016.

6 Na temat Cmentarza Stryjskiego zob. szerzej: J. Białynia Chołodecki, Cmentarz Stryjski, Lwów 1913.

7 Na temat Cmentarza Gródeckiego zob. szerzej: F. Jaworski, Cmentarz Gródecki, Lwów 1908.

8 Kronika. Na cmentarzu Eyczakowskim, Dziennik Polski, 10 VII 1881, nr 156. 
strony władz miejskich oraz niedofinansowanie działalności służby cmentarnej było widoczne także na drugim istniejącym wówczas w mieście Cmentarzu Stryjskim. We wrześniu 1882 r. podczas ceremonii pogrzebowej spuszczano do grobu trumnę ubogiej kobiety ale bez sznurów. Trumna spadła i pękła. Na pytanie uczestników ceremonii pogrzebowej, dlaczego nie ma sznurów, grabarz odpowiedział: „Sznury

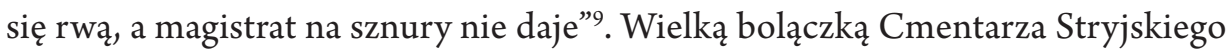
na początku lat osiemdziesiątych XIX w., i w następnych dekadach, gdy cmentarz był już nieczynny, był brak odpowiedniego ogrodzenia. Cmentarz „z powodu braku ogrodzenia - jak donosił latem 1881 r. „Dziennik Polski” - przystępny jest dla bydła i nierogacizny, na co zwracamy uwagę magistratu. Wszak to Lwów-stolica kraju! W sobotę podczas pogrzebu weterana Lewandowskiego okazało się, że grabarz wykopał za krótki grób i z tego powodu musiał w obecności duchowieństwa i osób należących do konduktu pogrzebowego rozszerzać jamę" ${ }^{10}$.

W schyłkowym okresie XIX w. w stołecznym mieście Lwowie, podobnie jak i w innych dużych miastach monarchii habsburskiej, powstawały prywatne, koncesjonowane zakłady pogrzebowe. W pierwszej kolejności należy wymienić zakład Antoniego Kurkowskiego, który był potentatem w zakresie usług pogrzebowych we Lwowie. Od lat osiemdziesiątych XIX w. prowadził wraz z bratem zakład pogrzebowy „Entréprise des Pompes Funebrés. Pierwszy koncesjonowany zakład pogrzebowy braci Kurkowskich”, mieszczący się przy ul. Sobieskiego 10, wraz z filią przy ul. Ormiańskiej 16. Zakład cieszył się we Lwowie dobrą opinią. „Firma braci Kurkowskich - donosiła ówczesna prasa - nie tylko ma uznanie jako zakład, lecz posiada zaufanie i szacunek w największych kołach naszego obywatelstwa, a to dlatego, że uczciwą pracą, rzetelnością, delikatnością i umiarkowanymi cenami, pozyskała sobie najzupełniejsze publiczne poparcie" ${ }^{11}$. W pierwszej połowie lat dziewięćdziesiątych XIX w. Antoni Kurkowski sam prowadził „Entréprise des Pompes Funebrés”. Zakład świadczył kompleksową obsługę pogrzebów. W latach osiemdziesiątych i w pierwszej połowie lat dziewięćdziesiątych XIX w. prężnie działała, zapewniając pełną obsługę pogrzebów, firma rodzinna „Concordia” Fryderyka Opuchlaka, która w prasie reklamowała się jako pierwszy lwowski zakład pogrzebowy. Zakład miał siedzibę przy placu Kapitulnym (Katedralnym) 8. Jak czytamy w reklamie z 1883 r.,

9 Kronika. Poszanowanie zmartych, Dziennik Polski, 28 IX 1882, nr 222; Kronika. Grabarz, Dziennik Polski, 1 X 1882, nr 224.

10 Kronika. Cmentarz stryjski, Dziennik Polski, 19 VII 1881, nr 163.

11 Nadestane, Nowa Iskra, VIII 1890. 
urządzał pogrzeby „począwszy od najskromniejszych aż do najwspanialszych dla wszystkich stanów, a wykonując ze znaną sumiennością jak najobszerniejsze zlecenia, uchyla wszelkie trudy pozostałej rodzinie" ${ }^{12}$. Zakład też handlował akcesoriami pogrzebowymi. Od 3 VII 1889 r. działał jako spółka jawna, pod nazwą „Concordia” Zakład Pogrzebowy F. Opuchlak i syn. Niestety, 1 III 1891 r. syn Emil Fryderyk Opuchlak, jawny wspólnik w spółce, został zamordowany siekierą przez kochankę Marię Kobrynową w swoim mieszkaniu przy ul. Skarbkowskiej 35. Niebawem dobrze działająca firma rodzinna przestała istnieć. Sąd Krajowy we Lwowie 29 VII 1893 r. wykreślił spółkę z rejestru handlowego ${ }^{13}$. Wówczas silną pozycję na rynku usług pogrzebowych miał zakład „Entréprise des Pompes Funebrés”. Poza wymienionymi należy wskazać na inne zakłady pogrzebowe, które wówczas prowadziły działalność we Lwowie. Były to „Elizium” Joanny Ostrowskiej, znajdujący się przy ul. Sobieskiego 9 (później „Veritas” przy ul. Piekarskiej 93) oraz działający od 1883 r. Zakład Pogrzebowy Stanisława Zdona przy ul. Ormiańskiej 18, a także utworzony na początku 1900 r. Zakład Pogrzebowy „Stella” Kazimierza Słotołowicza, mający swoją siedzibę przy ul. Wałowej 11. W 1906 r. „Stellę” kupił Antoni Kurkowski, który w tym czasie prowadzil firmę o nazwie „Concordia”. W ten sposób jego „Concordia” przez kilka następnych lat stała się monopolistą na lwowskim rynku usług pogrzebowych. Należy dodać, że ukraińskie zakłady pogrzebowe zaczęły powstawać dużo później, w okresie międzywojennym. Wówczas nacjonalizm ukraiński już akcentował swoją antypolskość na każdym polu, nawet głoszono, aby Ukraińca chował zakład pogrzebowy prowadzony przez Ukraińców. Pierwszy ukraiński zakład pogrzebowy „Charis” założył we Lwowie w 1933 r. Mychajło Halczak. Mieścił się w ukraińskim Narodnym Domu przy ul. Korniaktów 3. Zakład reklamował się również w prasie polskojęzycznej, podkreślając, że załatwia po „najtańszych” cenach wszelkie czynności związane z pogrzebami i ekshumacjami zwłok. Założyciel zakładu Halczak zmarł na emigracji w Nowym Jorku w 1970 r.

W ostatnich dwóch dziesięcioleciach XIX w. w zwyczaju pogrzebowym mieszkańców Lwowa przyjął się w szerszym zakresie nekrolog prasowy, w formie stosowanej po dzień dzisiejszy, czyli graficznie wyodrębnioną grubszą czarną obwódką

\footnotetext{
12 A. Kleczewski, Księga adresowa miasta Lwowa, Lwów 1883, s. 94. Concordia, Iskra, 1890, $\operatorname{nr} 67$.

13 Kronika miejscowa i zamiejscowa, Gazeta Narodowa, 3 III 1891, nr 53; Gazeta Lwowska, 28 VIIII 1889, nr 196; tamże, 25 VIII 1893, nr 193. Maria Kobrynowa za zabójstwo Emila Opuchlaka została skazana na karę śmierci. Cesarz aktem łaski zamienił karę śmierci na 18 lat ciężkiego więzienia. Z izby sądowej, tamże, 18 VIII 1891, nr 186.
} 
z krzyżem z informacją o śmierci i terminie pogrzebu, czasem o nabożeństwie żałobnym. W ramach szerszej oferty usługowej zakłady pogrzebowe w końcu XIX w. zamieszczały nekrologi w prasie lwowskiej, informujące o pogrzebach na Cmentarzu Łyczakowskim i Stryjskim, zdecydowanie mniej nekrologów informowało o pogrzebach na erygowanym w 1888 r. Cmentarzu Janowskim ${ }^{14}$. Jeżeli chodzi o nekrologi poświęcone zmarłym chowanym na nowopowstałej nekropolii janowskiej, z większą częstotliwością ukazywały się one w pierwszej dekadzie XX w. Nekrologi były publikowane $w$ ramach opłaty dokonywanej przez rodziny za organizację pogrzebu. Charakterystyczne otoczone czarną obwódką nekrologi z widoczną w stopce nazwą zakładu pogrzebowego ukazywały się głównie na łamach „Dziennika Polskiego”, „Kuriera Lwowskiego”, „Słowa Polskiego”, rzadko w urzędowej „Gazecie Lwowskiej”. Głównie zlecały je zakłady Antoniego Kurkowskiego „Entréprise des Pompes Funebrés” , następnie „Concordia” oraz zakłady „Concordia” Fryderyka Opuchlaka i „Stella” Kazimierza Słotołowicza. Nekrologi w prasie zlecały także zakłady Joanny Ostrowskiej i Stanisława Zduna. Opłata za wiersz petitowy nekrologu na przykład w redakcji „Dziennika Polskiego” w 1901 r. wynosiła 60 halerzy. Taką samą kwotę należało uiścić w 1906 r. w „Słowie Polskim”. Z czasem informację o pogrzebie w formie nekrologu podpisywali bliscy osoby zmarłej (mąż, żona, dzieci), a także różne organizacje zawodowe, związkowe i inne. Po uroczystości pogrzebowej częstym zwyczajem było zamieszczanie przez rodziny podziękowań w prasie dla uczestników pogrzebu. Należy dodać, że w polskich gazetach wychodzących we Lwowie ukazywały się w tym czasie również nekrologi informujące o pogrzebach na Cmentarzu Żydowskim. Na przełomie XIX i XX w. na łamach prasy lwowskiej ukazywały się też materiały wspomnieniowe, artykuły pośmiertne o zmarłych, znanych mieszkańcach miasta, których pogrzeby odbywały się głównie na Cmentarzu Łyczakowskim. Opinia publiczna bardzo rzadko mogła zapoznać się z krótkim pośmiertnym artykułem czy drobnym anonsem na temat zmarlych, chowanych na drugim działającym wówczas w mieście Cmentarzu Janowskim.

Lwowskie zakłady pogrzebowe prowadziły pełną obsługę uroczystości pogrzebowych, od wyprowadzenia zwłok z domu żałoby po pochówek, włącznie z zamieszczeniem nekrologów w prasie lwowskiej na życzenie rodzin zmarlych. Lwowskie prywatne zakłady pogrzebowe były dobrze funkcjonującymi przedsiębiorstwami, posiadały szeroką paletę usług i akcesoriów wykorzystywanych w czasie pogrzebów. Na przeło-

14 Na temat Cmentarza Janowskiego zob. szerzej: B. Patlewicz, R. Tomczyk, Cmentarz Janowski we Lwowie. Polskie dziedzictwo narodowe, t. I-II, Szczecin 2017. 
mie XIX i XX w. w ich ofercie było co najmniej sześć klas ceremonii pogrzebowych (od pierwszej ubogiej, do szóstej, bogatej w oprawę). Oferowane akcesoria pogrzebowe były zróżnicowane. Każdy zakład pogrzebowy posiadał skład trumien. Najtańsze, skromne trumny drewniane na początku lat dziewięćdziesiątych XIX w. kosztowały 2 floreny. Droższe były trumny dębowe politurowane, imitacje metalowych. W ofercie zakładów pogrzebowych były trumny metalowe ze znanej c.k. uprzywilejowanej fabryki Aleksandra Markusa Beschornera w Wiedniu. Szeroki wybór dotyczył wyposażenia trumny od obić z aksamitu i atłasu po różne materace, poduszki i kapy atłasowe, adamaszkowe, satynowe, organtynowe i inne. Zakłady pogrzebowe oferowały całą gamę wieńców metalowych z porcelanowymi kwiatami, z suszonych kwiatów, ze świeżych kwiatów (niezależnie od pory roku), wiązanek i różnokolorowych szarf z napisami lub bez. Były też spełniane mniej lub bardziej ekstrawaganckie zamówienia, jak chociażby srebrne wieńce. Do dyspozycji były karawany zabudowane i przeszklone. Powozy parokonne i jednokonne. Zakłady pogrzebowe oferowały także na zamówienie odpowiednio ubranych, w specjalne uniformy pracowników obsługujących ceremonie pogrzebowe. Była to jak nazywano we Lwowie tzw. służba w strojach hiszpańskich. Dla przewożenia zwłok zmarłych dzieci proponowano karawan i służbę w liberiach w kolorze niebieskim. Różnorodność w ubiorze osób zatrudnionych do obsługi pogrzebów budziła czasem niezadowolenie i krytykę. Między innymi część radnych miejskich w pierwszej dekadzie XX w. chciało „usunąć teatralną komediancką pompę, ubliżającą powadze pogrzebu", głośno domagali się, aby pracownicy zakładów pogrzebowych nie byli przebrani „za Hiszpanów, Madziarów, wojewodów, co przynosi ujmę temu poważnemu obrzędowi”"15. Wcześniej, 13 III 1902 r., rada miasta przyjęła uchwałę, na mocy której zakazano reklamowania na chodnikach, przed zakładami pogrzebowymi różnych akcesoriów pogrzebowych.

Wysokie koszty pogrzebu były problemem dla rodzin ubogich, w których pojawiła się śmierć. Rodziny nie były w stanie zapewnić zmarłym bliskim odpowiedniej oprawy w ostatniej drodze na cmentarz. Oprawa pogrzebów i kondukty żałobne ludzi ubogich były skromne, z udziałem najbliższej rodziny, grona sąsiadów. Niekiedy zachowanie pracowników obsługujących pogrzeby ubogich budziło oburzenie osób idących w kondukcie, jak to miało miejsce w przypadku pogrzebu dziecka jednego z majstrów szewskich, który się odbył w połowie czerwca 1897 r. Posługacz z obsługującego uroczystości pogrzebowe uboższych warstw mieszańców Lwowa, zakładu pogrzebowego „Elizium” Joanny Ostrowskiej, niosąc trumnę w drodze na Cmentarz Janowski upu-

15 Rada miejska, Słowo Polskie, 7 X 1906, nr 249. 
ścił ją na ziemię. Odchyliło się wieko trumny, a zwłoki dziecka niemal nie wypadły na chodnik. Jak się okazało pracownik zakładu pogrzebowego był pijany. Biednych rodziców nie stać było na opłacenie uroczystej oprawy pogrzebu z karawanem lub wynajęcie bardziej renomowanego i profesjonalnie wykonującego swoją pracę zakładu pogrzebowego ${ }^{16}$. Ten i inne gorszące przypadki, które miały miejsce podczas pogrzebów osób ubogich spowodowały reakcję władz miejskich. Rada miasta podjęła 13 III 1902 r. uchwałę, dyscyplinując wszystkie działające we Lwowie zakłady pogrzebowe. Zawarła w niej instrukcję dla przedsiębiorców pogrzebowych, która unormowała postępowanie posługaczy pogrzebowych podczas pogrzebu ${ }^{17}$. Część radnych miejskich dostrzegała problem wysokich cen za usługi pogrzebowe w mieście. W pierwszym dziesięcioleciu XX w. przeciętnie lwowianie wydawali na opłacenie kosztów pogrzebu od 100 do ponad 300 koron. Niekiedy, w przypadku osób zmarlych, które za życia były zrzeszone w różnych organizacjach zawodowych (cechowych) i związkowych, to one brały na siebie część kosztów pogrzebu. Wśród radnych miejskich nie brakowało takich, którzy uważali, że wobec wzrastającej konkurencji na rynku usług pogrzebowych koszty pogrzebów będą spadać. Wskazywali, że w przy takim trendzie na rynku usług, już przyzwoity pogrzeb mógł być zorganizowany za sumę 100 koron ${ }^{18}$. Władze miasta chciały mieć wpływ na ceny usług pogrzebowych, szczególnie aby unormować sytuację w obszarze pogrzebów biednych mieszkańców miasta. Magistrat dążył do posiadania własnego komunalnego zakładu pogrzebowego, który świadczyłby usługi również dla biednych mieszkańców miasta, a jednocześnie w miarę potrzeby pełniłby rolę domu przedpogrzebowego. W dużych miastach monarchii habsburskiej władze dostrzegały problem z pochówkami osób ubogich. Prywatne zakłady pogrzebowe często działały w oparciu o agentów, stających się pełnomocnikami głównie lepiej sytuowanych krewnych zmarłego i załatwiali sprawy związane z organizacją pogrzebu. Nie były one zainteresowane pochówkami zmarłych z rodzin biednych. Utworzenie komunalnego zakładu pogrzebowego nie było pomysłem nowym. Takie zakłady tworzyły samorządy miejskie w monarchii habsburskiej. Na przykład władze Wiednia, aby unormować sytuację z pochówkami osób ubogich, wykupiły w 1907 r. dwa największe prywatne zakłady pogrzebowe i na ich bazie stworzyły miejskie przedsiębiorstwo pogrzebowe. Delegacja urzędu i radnych Lwowa wizytowała między innymi miejski zakład pogrzebowy w Dreźnie. Władze Lwowa po długich dyskusjach zdecydowały się

\footnotetext{
16 Wypadek na pogrzebie, tamże, 15 VI 1897, nr 137.

17 Rada miasta Lwowa, Gazeta Lwowska, 15 III 1902, nr 61.

18 Rada miejska, Słowo Polskie, 7 X 1906, nr 249.
} 
zakupić jeden z działających już zakładów pogrzebowych i przekształcić go w zakład komunalny. Magistrat otrzymał kilka ofert kupna. Najpoważniejszą ofertę sprzedaży zgłosił Antoni Kurkowski, właściciel zakładu pogrzebowego „Concordia”. Przy tym zadeklarował chęć objęcia kierownictwa takiego nowoutworzonego miejskiego zakładu. Powołana komisja ds. zakładu pogrzebowego oszacowała w połowie $1906 \mathrm{r}$. wartość „Concordii” Kurkowskiego na kwotę 111000 koron, zaś właściciel najpierw zażądał 300 000, następnie 285000 koron, przy czym dopuszczał płatność w ratach ${ }^{19}$. Rozmowy na temat kupna zakładu pogrzebowego „Concordia” Kurkowskiego trwały trzy lata. Na posiedzeniu komisji ds. zakładu pogrzebowego w połowie lutego $1909 \mathrm{r}$. rozpatrzono kolejną ofertę Kurkowskiego w wysokości 234000 koron za całość składników majątkowych, czyli nieruchomości (biura, dom przedpogrzebowy), dorożki, powozy, karawany, konie, garderoba karawaniarzy, niezbędne akcesoria, itd. Komisja jednogłośnie opowiedziała się za przyjęciem oferty ${ }^{20}$. Jednocześnie na żądanie magistratu Kurkowski złożył oświadczenie, że w przyszłości nie będzie prowadził kolejnego zakładu pogrzebowego w mieście. Rada miejska ostatecznie przyjęła uchwałę o zakupie największego we Lwowie prywatnego zakładu pogrzebowego „Concordia” Kurkowskiego. Transakcja została sfinalizowana i od 1 V 1909 r. rozpoczął pracę Miejski Zakład Pogrzebowy „Concordia”, który mieścił się przy ul. Sobieskiego 16. Zakład świadczył szeroki zakres usług pogrzebowych, posiadając niezbędne karawany i inne akcesoria pogrzebowe. W pierwszym okresie działalności stosował $10 \%$ upustu dla swoich klientów od cen, które obowiązywały jak zakład był w rękach Antoniego Kurkowskiego ${ }^{21}$.

Miejski Zakład Pogrzebowy „Concordia”, działający na zasadach jednostki organizacyjnej magistratu posiadał odrębny budżet. Pierwszy rok działalności miejskiej instytucji pogrzebowej przyniósł skromny zysk finansowy. Od 1 V 1909 r. do 30 IV 1910 r. Miejski Zakład Pogrzebowy obsłużył 1468 pogrzebów, głównie na Cmentarzu

19 Rada miasta Lwowa, Dziennik Polski, 7 VI 1906, nr 252.

20 Komisja zakładu pogrzebowego, Dziennik Polski, 15 II 1909, nr 82; Kronika, Kurier Lwowski, 13 II 1909, $\mathrm{nr} 72$.

21 Rodzinie Kurkowskich życie nie oszczędziło tragicznych wydarzeń. W nocy z 29 na 30 IV 1934 r. samobójstwo popełnił Julian Kurkowski, syn Antoniego, także lwowski przedsiębiorca pogrzebowy. Prowadził własny zakład pogrzebowy przy ul. Sobieskiego 9, następnie od 15 XI 1931 r. do 17 X 1933 r. pełnił funkcję kierownika Miejskiego Zakładu Pogrzebowego „Concordia”. Później ponownie uruchomił własny zakład pogrzebowy przy ul. Sobieskiego 12. Właśnie w magazynie trumien w tym zakładzie odkręcił gaz. Powodem samobójstwa była trudna sytuacja finansowa. Ze spraw miejskich, Kurier Lwowski, 19 XI 1931, nr 321; Gaz wśród trumien. Samobójstwo wtaściciela zakładu pogrzebowego, Nowiny Codzienne, 1 V 1934, nr 118. 
Łyczakowskim i Janowskim, a także na podmiejskich cmentarzach. $\mathrm{Z}$ tej liczby pogrzebów za 1000 koron był 29; za 900 - 6; za 800 - 13; za 700 - 23; 600 - 26; za 500 - 43; za 400 - 78; za 300 - 97; za 200 - 183; za 100 - 325; za 50 - 325; od 13 do 45 $\mathrm{Kr}$ - 320 pogrzebów. Z kolei w 1911 r. Miejski Zakład Pogrzebowy obsłużył 1361 pogrzebów, z czego za $1000 \mathrm{Kr}$ było 27 pogrzebów; do $200 \mathrm{Kr}$ - 302; do 100-284; do 50-259. Łącznie od początku funkcjonowania zakładu do trzeciego kwartału $1913 \mathrm{r}$. Miejski Zakład Pogrzebowy obsłużył 11212 pogrzebów. Z tej liczby 6885 to pogrzeby zwykłe osób dorosłych, 2258 to pogrzeby dziecięce, 192 - wojskowe, 1877 $\operatorname{arymatejskie}^{22}$. Było to ok. 2/3 wszystkich pogrzebów chrześcijańskich. Pozostałe obsługiwały zakłady prywatne ${ }^{23}$. Miejski Zakład Pogrzebowy stał się monopolistą na rynku usług pogrzebowych. Stan taki praktycznie utrzymał się do wybuchu drugiej wojny światowej. Niemniej będąc miejskim zakładem budżetowym prowadząc obsługę pogrzebów zmarłych z rodzin ubogich, które nie miały czasem pieniędzy na opłaty pogrzebowe, w kolejnych latach przed wybuchem pierwszej wojny światowej generował zadłużenie. W takich sytuacjach, trzymając się litery prawa, rada miejska podejmowała decyzję o zaskarżeniu dłużników w celu ściągnięcia zaległych opłat. Taką decyzję podjęła na posiedzeniu rada miejska 5 II 1914 r. Sytuacja finansowa zakładu uległa poprawie w okresie działań wojennych i okupacji miasta podczas pierwszej wojny światowej, kiedy to zwiększyła się wówczas śmiertelności w mieście.

Należy dodać, że w 1911 r. członkowie zarządu szkoły im. Marii Konopnickiej w Dawidowie pod Lwowem, która jako jedyna w Galicji uczyła biedne wiejskie dziewczęta wyrobu sztucznych kwiatów i wieńców pogrzebowych, zwracali się do prezydenta Lwowa o zakup przez Miejski Zakład Pogrzebowy wieńców pogrzebowych, które do tej pory były zamawiane w innych częściach monarchii habsburskiej. Zakład potrzebował wówczas od 40 do 50 wieńców tygodniowo. Wieńce wykonane w szkole w Dawidowie były sprzedawane w lokalu Ligi Pomocy Przemysłowej we Lwowie $^{24}$. Promocja rękodzieła rozwijającego się na prowincji stanowiła też próbę zastąpienia wieńców przywożonych z głębi Austrii. Niemniej szereg akcesoriów pogrzebowych nadal pochodził spoza Galicji.

22 Towarzystwo św. Józefa z Arymatei zajmowało się organizowaniem pogrzebów osób z rodzin biednych. W 1905 r. posiadało we Lwowie 544 członków i w tym roku zorganizowało 373 pogrzeby dla osób ubogich, wydając na ten cel 3087 koron. J. Wiczkowski, Lwów. Jego rozwój i stan kultury oraz przewodnik po mieście, Lwów 1907, s. 494.

23 Miejski Zakład Pogrzebowy, Dziennik Polski, 23 V 1910, nr 137; Kronika, Kurier Lwowski, 6 I 1912, nr 8; tamże, 22 XII 1913, nr 586.

Kronika, Goniec, 1 II 1911, nr 1211; tamże, 20 X 1911, nr 1425. 
We Lwowie dużą bolączką był brak domów przedpogrzebowych. W takiej sytuacji funkcjonujące $w$ mieście zakłady pogrzebowe pełniły ważną funkcje domów przedpogrzebowych, ale tylko w przypadku, gdy zmarły pochodził z rodziny dobrze sytuowanej finansowo. Taką rolę spełniała też krypta kościoła oo. Bernardynów. We Lwowie na przełomie XIX i XX w. lekarz miejski zgłaszał postulat do rady miejskiej budowy domów przedpogrzebowych. Takie domy funkcjonowały na terenie zjednoczonych Niemiec, wcześniej poszczególnych państw niemieckich. W Weimarze działały już w 1800 r., w Moguncji od 1805 r, w Monachium od 1819 r., we Frankfurcie nad Menem od $1828 \mathrm{r}$. W Berlinie na początku XX w. było 45 domów przedpogrzebowych. Wniosek budowy domów przedpogrzebowych w 1900 r. przedstawił również prezydent miasta Godzimir Małachowski. Były to postulaty zarówno natury sanitarnej, jak i etycznej. W stolicy kraju koronnego, warunki mieszkaniowe ubogich rodzin były złe. Prasa alarmowała: „Zdarza się, że śmierć zawita do domu nędzarza, mieszczącego się z bardzo liczną rodziną i podnajemcami w jednej dusznej, niemającej światła izbie, pośrodku izby ustawia się katafalk ze zwłokami, a dokoła przesuwają się, gotują i spożywają strawę codzienną i śpią pod katafalkiem żywi. Zdarza się dalej, że w takiej tłumnie zamieszkałej izdebce trzeba wystawić zwłoki człowieka, zmarłego na chorobę zakaźną. W innej ubogiej rodzinie, wystawienie zwłok na katafalku zbiega się z faktem obłożnej choroby innych mieszkańców tej izby. Na dzieci i osoby $\mathrm{z}$ nadwątlonym systemem nerwowym sąsiedztwo trupa działa niesłychanie denerwująco w dzień, a cóż dopiero w nocy! ${ }^{25}$ W rodzinach lepiej sytuowanych, które posiadały wielopokojowe mieszkania lub domy jednorodzinne sytuacja była naturalnie lepsza, często w takich okolicznościach pracownicy zakładów pogrzebowych obijali kirem pokój, w którym leżał w trumnie zmarły, aż do chwili wyprowadzenia zwłok na cmentarz. Do domu żałoby przychodzili ludzie, którzy żegnali się ze zmarłym i wspierali w tym trudnym czasie zrozpaczoną jego rodzinę. Domy przedpogrzebowe były potrzebne także z innych powodów, na przykład w przypadku osób przyjezdnych, których śmierć nagle i niespodziewanie dosięgnęła w stolicy Galicji, lub wówczas, gdy trzeba było przechować zwłoki nieznanych samobójców lub żebraków. W takich przypadkach jedynym miejscem, jakim urząd miejski dysponował, była kostnica na Cmentarzu Janowskim. Wraz z utworzeniem Miejskiego Zakładu Pogrzebowego w szerszym zakresie zaczął funkcjonować dom przedpogrzebowy przy ul. Kochanowskiego 64, w pomieszczeniach zakładu pogrzebowego „Concordia” (później także w innym pomieszczeniu tego zakładu przy ul. Kochanowskiego 96). 
W 1912 r. w stylu modernistycznym według projektu Romana Felińskiego i Jerzego Grodyńskiego został wybudowany dom przedpogrzebowy obok Cmentarza Żydowskiego (został wysadzony w powietrze przez Niemców wiosną $1943 \mathrm{r}$.

W 1904 r. rozpoczęła się budowa kościoła św. Elżbiety ${ }^{26}$, w tym czasie radny Karol Sklepiński zgłaszał wniosek o zapisanie w budżecie miasta na 1904 r. dodatkowej kwoty na urządzenie przy nim krypty, która odpowiednio wyposażona mogłaby służyć za dom przedpogrzebowy dla dzielnicy Gródeckiej. Większość zmarłych w tej części miasta była chowana na Cmentarzu Janowskim. Niemniej wówczas miejskie służby sanitarne opowiadały się za budową domu przedpogrzebowego obok Cmentarza Łyczakowskiego. Jednak do realizacji inwestycji nie doszło. W kolejnych latach radni miejscy zgłaszali postulaty budowy domów przedpogrzebowych. Domagali się tego mieszkańcy Lwowa. W 1910 r. mieszkańcy miasta zgłosili postulat budowy domów przedpogrzebowych w każdej dzielnicy. Proponowano realizację takich inwestycji na terenach przykościelnych, na przykład przy kościele bernardyńskim, św. Marii Magdaleny, św. Antoniego, św. Marcina. Domy przedpogrzebowe miały pod względem architektonicznym nie odbiegać od stylu poszczególnych kościołów. Pojawiły się w tym czasie także głosy, aby zakazać przemarszów konduktów pogrzebowych, które tamowały ruch uliczny w mieście ${ }^{27}$. Poruszające się wolno kondukty pogrzebowe głównymi ulicami prowadzącymi w kierunku Cmentarza Łyczakowskiego i Janowskiego stanowily dużą niedogodność w czasach, gdy na ulicach miasta nasilał się ruch zarówno wozów konnych, jak i tramwajów oraz samochodów. W mieście obowiązywała zasada, aby kondukty pogrzebowe zmierzały na cmentarze jak najkrótszą trasą.

Pierwsza wojna światowa to czas wysokiej śmiertelności we Lwowie. W 1914 r., w pierwszych miesiącach okupacji rosyjskiej we Lwowie, według sprawozdań fizykatu miejskiego ogniska epidemii chorób zakaźnych występowały one przeważnie w dzielnicy Żółkiewskiej i Gródeckiej, czyli w okręgu cmentarnym przypisanym uchwałą rady miasta do Cmentarza Janowskiego. Aby zapobiec rozszerzeniu się epidemii w mieście nakazano właścicielom nieruchomości utrzymania czystości w obejściach. Z kolei właścicielom zakładów pogrzebowych nakazano dezynfekcję wszystkich urządzeń, służących do dekoracji uroczystości pogrzebowych w domach

26 Kościół św. Elżbiety był budowany w latach 1904-1911. Poświęcenie kościoła odbyło się 22 X 1911 r. z udziałem arcybiskupa Józefa Bilczewskiego. Kronika, Goniec, 23 X 1911, nr 1427. Rada miejska z budżetu miasta wydała co najmniej 500000 koron na jego budowę. Jak powiadano we Lwowie był to kościół kolejarzy, którzy licznie zamieszkiwali okolicę.

27 Miejski Zakład Pogrzebowy, Dziennik Polski, 23 V 1910, nr 137. 
żałoby. Na wniosek lekarza miejskiego został wprowadzony zakaz ustawiania katafalków, kotar żałobnych, świeczników, kwiatów i innych akcesoriów dekoracyjnych w domach osób zmarłych. Zakaz nie dotyczył domów przedpogrzebowych. Jednocześnie Rada Sanitarna we Lwowie jesienią 1914 r. apelowała do rosyjskich władz wojskowych o przewożenie zmarłych na cholerę żołnierzy w szczelnych trumnach. W drugiej połowie 1915 r., po wyjściu wojsk rosyjskich sytuacja zdrowotna w mieście się częściowo poprawiła, nadal jednak była zła. Częste kondukty pogrzebowe przemieszczające się ulicami miasta spowodowały reakcję komendanta miasta, którym był Czech gen. Wojciech Letovsky. W porozumieniu z władzami miasta ze względu na czas wojenny postanowił przywrócić moc dawnego zarządzenia o poruszaniu się konduktów pogrzebowych na cmentarz najkrótszą drogą. Zwłoki zmarłych miały być eksportowane z pominięciem domów przedpogrzebowych. Do tego pogrzeby zmarlych poza granicami miasta miały się odbywać jedynie od bramy cmentarnej do grobu. Komendant miasta zarządził także, aby we Lwowie, gdzie w jego ocenie panowały fatalne warunki sanitarne, został wybudowany nowy dom przedpogrzebowy. Jednak inwestycja w tym czasie nie została zrealizowana. Kolejne inwestycje związane z domami przedpogrzebowymi zrealizowano w okresie międzywojennym przy kościele oo. Reformatów oraz św. Elżbiety.

Pogrzeby cywilne we Lwowie w okresie międzywojennym miały nadal zróżnicowaną oprawę, od wystawnej, po bardzo skromną. Podobnie jak w latach minionych były widoczne, tak głęboko wrośnięte w krajobraz lwowskich ulic, częste kondukty żałobne, które wyruszały z domów żałoby na Cmentarz Łyczakowski lub Janowski i hamowały ruch uliczny, co szczególnie w śródmieściu powodowało problemy komunikacyjne. Jak wspominał Jan Dziedzic, świadek takich pogrzebów w okresie międzywojennym, ważniejszych zmarłych lwowian odprowadzało „liczne duchowieństwo, szeregi kleryków w białych komżach, żałobnicy w stosownych kapeluszach, ciągniony przez czwórkę karych koni bogato zdobiony karawan o spowitych kirem latarniach, w których migotały płomyki świec"28. Bogatsi żałobnicy w trakcie drogi na cmentarz w tym czasie nadal korzystali z karet ciągnionych przez konie, gdyż jazda samochodem na cmentarz była uważana za coś niewłaściwego, w złym stylu. Oczywiście zdecydowana większość konduktów pogrzebowych, w tak uroczystej oprawie, z udziałem dużej liczby duchownych i żałobników kierowała się w okresie międzywojennym na Cmentarz Łyczakowski. Cmentarz Janowski był postrzegany jako miejsce pochówków uboższych warstw lwowian. Niemniej spoczął tutaj 24 IV 
1923 r. arcybiskup Józef Bilczewski. Jego pogrzeb był jedną z największych uroczystości żałobnych w historii miasta. Większość pogrzebów na tym cmentarzu miała skromną oprawę, często z niewielką liczbą osób podążających w kondukcie żałobnym. Niemniej prawie zawsze w kondukcie żałobnym uczestniczyło duchowieństwo katolickie. Naturalnie zdarzały się pogrzeby, w których ksiądz nie brał udziału. Dotyczyło to głównie pochówków samobójców czy morderców oraz zmarłych przedstawicieli nurtu komunistycznego.

W okresie międzywojennym we Lwowie zdecydowanie mniej pojawiało się nekrologów w miejscowej prasie. Krewni nie podawali do szerokiej wiadomości publicznej informacji o śmierci swoich bliskich i terminie pogrzebu w formie nekrologów prasowych, szczególnie w odniesieniu do pogrzebów na Cmentarzu Janowskim. W prasie ukazywały się głównie nekrologi zmarlych, którzy byli chowani na Cmentarzu Łyczakowskim. Za to szeroko upowszechnił się zwyczaj rozwieszania na drzwiach, ścianach i tablicach ogłoszeń przy kościołach oraz innych wyznaczonych miejscach publicznych nekrologów, drukowanych indywidualnie przez rodziny, na zlecenie Miejskiego Zakładu Pogrzebowego „Concordia” przy ul. Sobieskiego 16. Następnie zakładów prywatnych, na przykład Zakładu Pogrzebowego „Elizjum” (ul. Sobieskiego 9), Zakładu Pogrzebowego Juliana Kurkowskiego przy ul. Sobieskiego 12, Zakładu Pogrzebowego Stanisława Zdona (ul. Ormiańska 18), Powszechnego Zakłada Pogrzebowego W. Skrema (plac Bernardyński 2) czy pierwszego ukraińskiego Zakładu Pogrzebowego „Charis”, mieszczącego się przed wybuchem drugiej wojny światowej przy ul. Rutowskiego. Charakterystyczne nekrologii w czarnej ramce były drukowane między innymi w drukarniach: Antoniego Gojawiczyńskiego przy ul. Kopernika 20; Czesława Wernera przy ul. Sobieskiego 18; przy ul. Łyczakowskiej 3 (istniała od 1773 r., od końca XIX w. działała pod nazwą Piller-Neumann i Spółka); przy ul. Piekarskiej 20 (w czasie drugiej wojny światowej, w okresie okupacji niemieckiej Buchdruckerei nr 7, Piekarskastresse 20).

W okresie drugiej wojny światowej, poza konduktami pogrzebowymi wyruszającymi z domów na terenie miasta, zwanych nadal tradycyjnie „domami żałoby”, nie mała część pogrzebów odbywała się bez ulicznego konduktu pogrzebowego. Uroczystości pogrzebowe odbywały się bezpośrednio na cmentarzu, gdzie wyprowadzenie zwłok miało miejsce z kaplic cmentarnych. W czasie wojny, na przykład na Cmentarz Janowski często kondukty żałobne wyruszały z pobliskiej krypty przy kościele oo. Reformatów, przy ul. Janowskiej 66.

Przez dziesięciolecia istniał szeroko rozpowszechniony zwyczaj pogrzebowy we Lwowie, silnie powiązany z tradycją katolicką. Po zakończeniu drugiej wojny 
światowej, w okresie rządów radziecko-ukraińskich nadal mimo prześladowań duchowieństwa, mieszkańcy Lwowa starali się o to, aby na pogrzebach ich bliskich była żałobna posługa księdza. Chociaż w tym czasie, szereg pogrzebów na cmentarzach miało charakter świecki. Niereligijna ceremonia pochówku była skierowana do działaczy partyjnych, ale również do ateistów, agnostyków. Współcześnie, w wyniku odrodzenia religijnego na Ukrainie, ceremonie pogrzebowe są głównie z udziałem duchownych. Odbywają się one także na oficjalnie zamkniętych od wielu lat cmentarzach: Łyczakowskim, Janowskim czy Zamarstynowskim. Z braku miejsca, przeważnie kosztem starszych pochówków, bardzo często z inskrypcją nagrobną w języku polskim.

Nadesłany: 15 III 2017

Nadesłany po poprawkach recenzyjnych: 15 XII 2017

Zaakceptowany: 21 XII 2017

dr hab. RYsZard TOMCZYK, prof. US

Instytut Historii i Stosunków Międzynarodowych

Wydział Humanistyczny

Uniwersytet Szczeciński

ul. Krakowska 71-79

71-017 Szczecin

rtomczyk10@wp.pl

\section{Burial rituals and funerary services in the Polish community in Lvov in the late $19^{\text {th }}$ and the early $20^{\text {th }}$ centuries}

In the late $19^{\text {th }}$ century, the larger cities in Galicia including the capital city of Lvov followed the example of large centres in the Habsburg empire where private, licensed funeral parlours were established, rendering comprehensive funerary services. In the first decade of the $19^{\text {th }}$ century, the Lvov authorities decided to affect the prices of funerary services. One of the reasons was intention to offer standard funerary services to the city's poor inhabitants. The magistrate's goal was to have its own communal funeral parlour which would also handle funerals of the city's less affluent inhabitants. In 1909, the "Concordia" Municipal Funeral Parlour started operations. In the Polish community in Lvov, the burial ritual was directly related to the Catholic tradition. In the last two decades of the $19^{\text {th }}$ century, an obituary published in the press made its way to the burial ritual in Lvov in the form still used today i.e. 
information about the death and the date of the funeral, sometimes also about a memorial service, graphically marked with a thick black border with a cross. The funerary ritual which emerged at that time remained largely unchanged in the Second Polish Republic (1918-1939). The situation changed after WWII when Lvov was under the Soviet and Ukrainian rule. While in this difficult time the Catholic church was persecuted, Poles living in Lvov made an effort to invite a priest to funerals of their next of kin.

Translated by: Ewa Dratwa 